\title{
Impact of Sorghum and Nabag (Ziziphusspina-Christi) Pulp Fruit Lactic Acid Bacteria Sourdoughs on Fermentation Properties of Dough, Quality and Shelf Life of Wheat Bread
}

\author{
Emad Mohamed Ali Karrar ${ }^{1,2}$, Weining Huang, ${ }^{1, *}$ Feng Wang ${ }^{1}$, Chun Li Jia ${ }^{1}$ \\ ${ }^{1}$ The State Key Laboratory of Food Science and Technology, School of Food Science and Technology, International Exchange and \\ Cooperation Program, Jiangnan University, Wuxi, Jiangsu, PR China \\ ${ }^{2}$ Department of Food Science and Technology, Faculty of Engineering and Technology, University of Gezira, Wad Medani, Sudan
}

Email address:

wnhuang@jiangnan.edu.cn (Weining Huang), emadkarrar26@yahoo.com (E. M. A. Karrar)

${ }^{*}$ Corresponding author

\section{To cite this article:}

Emad Mohamed Ali Karrar, Weining Huang, Feng Wang, Chun Li Jia. Impact of Sorghum and Nabag (Ziziphusspina-Christi) Pulp Fruit Lactic Acid Bacteria Sourdoughs on Fermentation Properties of Dough, Quality and Shelf Life of Wheat Bread. American Journal of Health Research. Vol. 4, No. 2, 2016, pp. 30-38. doi: 10.11648/j.ajhr.20160402.13

Received: March 19, 2016; Accepted: March 24, 2016; Published: March 31, 2016

\begin{abstract}
Sourdoughs were produced from sorghum and nabag flour using Lactobacillus plantarum and L. brevis and added to a basic bread formulation (10\% and $20 \%$ addition levels). Dough fermentation, quality and shelf life of wheat bread were examined. Acidification characteristics ( $\mathrm{pH}$ and total titratable acidity), total bacteria count, fermentation end-products (malic acid, lactic acid, acetic acid, citric acid, succinic acid, fumaric acid and ethanol) and soluble carbohydrates (arabinose, galactose and glucose) contents were measured during both sorghum sourdough and nabag sourdough. Some differences between $L$. plantarum and L. brevis in acidification properties, fermentation end-products and soluble carbohydrates availability were observed both in sorghum sourdough and nabag sourdough. Addition of sorghum and nabag sourdough starters progressively decrease $\mathrm{pH}$ and increased TTA values compared to the control dough and bread. Addition of sorghum and nabag sourdough significantly decreased dough water absorption and increased maximum gas fermentation height, total gas volume, gas retention volume, thereby sorghum and nabag sourdough has positive effect to improve of the fermentation properties of dough. The results showed that dough prepared with $10 \%$ and $20 \%$ sorghum and nabag sourdough starters had a positive impact on bread quality properties, whereas nabag sourdough starters showed higher volume and moisture content and better textural properties during storage than samples of sorghum sourdough and control.
\end{abstract}

Keywords: Sorghum Sourdoughs, Nabag Sourdoughs, Lactic Acid Bacteria, Quality of Bread

\section{Introduction}

Sourdough fermentation is one of the oldest biotechnological processes for the production of bread. Sourdough, a mixture of flour and water fermented with lactic acid bacteria and/or yeast, are use to improve the quality of wheat bread [1]. The addition of sourdough previously served to improve flavour, texture, shelf life and nutritional properties of bread [2]. Sorghum [Sorghum bicolor (L.) Moench] is a traditional crop in Africa that is safe for consumption by celiac patients [3, 4]. In recent years sorghum has received increasing attention due to its functional properties, prevention of chronic diseases, polyphenolic compounds, and as a potential raw material in gluten-free diet $[4,5]$. Fermentation of gluten-free flours has previously been shown to improve overall bread quality $[2$, 6]. The positive effects are linked to metabolites produced by lactic acid bacteria (LAB) during sourdough fermentation, including organic acids, exopolysaccharides (EPS) and enzymes. There is consensus regarding the positive effects of sourdough addition for bread production, including improvement in bread volume, crumb structure, flavor and shelf-life $[7,8]$.

Lactic acid fermentation is used in fermentation of milk, vegetables (cucumber, cabbage, and cassava), cereal (wheat, 
sorghum, maize) and fruits (mango, orange, banana and pineapple). Fermentation plays an important role in preservation of food. Lactic acid bacteria (LAB) fermentation in Fruits produces metabolites such as organic acids and exopolysaccharides [9]. Ziziphusspina-christi (family Rhamnaceae) is tropical evergreen tree widely spread in Asia, Africa and America. The fruit is locally known by its Arabic name nabag while in other countries is known as Christ's thorn jujube [10]. The fruit is rich source of carbohydrates, vitamins and minerals. The dry fruit contains 314 calories per $100 \mathrm{~g}, 9.3 \%$ moisture, $4.1 \%$ protein, $3.4 \%$ fat, $80.6 \%$ total carbohydrate, $3.5 \%$ ash; $499 \mathrm{mg} \mathrm{Ca}, 17.9 \mathrm{mg}$ $\mathrm{Fe}, 0.04 \mathrm{mg}$ thiamin, $0.13 \mathrm{mg}$ riboflavin, $3.7 \mathrm{mg}$ niacin and 96 to $500 \mathrm{mg}$ of ascorbic acid [10,11,12]. Availability of certain specific nutrients in fruits such as vitamins, minerals can be helpful for fermentation by LAB [9]. Fermented food metabolized by lactic acid bacteria (LAB) enhances food safety and prolongs shelf life thus aiding in food preservation [13]. In this study, two strains of bacteria (Lactobacillus brevis and L. plantarum) were used for sorghum and nabag sourdough fermentation. These strains were selected for their complementary fermentation properties. L. brevis is heterofermentative and produces a mixture of lactic acid, ethanol, acetic acid and $\mathrm{CO}_{2}$ while $L$. plantarum (homofermentative) produces lactic acid and contains tannase which metabolizes phenolic acids and esters of phenolic acids [14], and also L. plantarum is one of the species of lactic acid bacteria famous for fermenting vegetables and fruits. This study investigates the suitability of L. plantarum and L. brevis, as starter culture for sorghum and nabag sourdoughs fermentation. Furthermore, influence of addition of sorghum and nabag (Ziziphus spina-christi) pulp fruit sourdoughs with L. plantarum and L. brevis on fermentation properties of dough, quality and shelf life of wheat bread.

\section{Materials and Methods}

\subsection{Materials}

High-gluten wheat flour, white sorghum flour, dry yeast, salt, sugar, and butter we purchased in a local market. Dry nabag fruit was purchased from a local farm in Wad Medani City, Gezira State, Sudan. Moisture, ash, and protein contents were determined by AACCI 2000 Approved Methods 4415.02A, 08-01.01, and 46-13.01, respectively. Dry nabag fruit were pitted manually, grounded into powder by a hammer mill and stored at $-20^{\circ} \mathrm{C}$ until needed.

\subsection{Microorganisms and Growth Conditions}

The strains L. plantarum and L. brevis were previously isolated from wheat sourdoughs at the Laboratory of Baking Science and Ingredient Functionality Research, School of Food Science and Technology, Jiangnan University, P. R. of China were used in this study. The strains were used singly as culture starters in sourdough fermentation. Lactobacillus strains were grown in MRS broth at $37^{\circ} \mathrm{C}$ for $24 \mathrm{~h}$ and stored at $4{ }^{\circ} \mathrm{C}$ until use; pure stocks were stored at $-20^{\circ} \mathrm{C}$ in glycerol $(1: 1 \mathrm{v} / \mathrm{v})$.

\subsection{Sourdough Fermentation}

Sourdough starters were prepared at sorghum and nabag flour: water ratio of $1: 1(\mathrm{w} / \mathrm{v})$ and inoculated with $0.5 \mathrm{~g}$ strain pellet ( $\mathrm{LP}$ and $\mathrm{LBr}$ ). The starters were incubated at $37^{\circ} \mathrm{C}$ for $24 \mathrm{~h}$. Each sourdough was individually fermented according to the formula: $\mathrm{S}_{\mathrm{LP}}-100 \mathrm{~g}$ of sorghum flour, $100 \mathrm{~g}$ of distilled water (Dough yield $=200$ ) with $0.5 \mathrm{~g}$ strain $(\mathrm{LP})$, and $\mathrm{S}_{\mathrm{LBr}}$ $100 \mathrm{~g}$ of sorghum flour, $100 \mathrm{~g}$ of distilled water (Dough yield $=200$ ) with $0.5 \mathrm{~g}$ strain $(\mathrm{LBr}), \mathrm{N}_{\mathrm{LP}}-100 \mathrm{~g}$ of Nabag flour, $100 \mathrm{~g}$ of distilled water (Dough yield $=200$ ) with $0.5 \mathrm{~g}$ strain (LP), and $\mathrm{N}_{\mathrm{LBr}}-100 \mathrm{~g}$ of Nabag flour, $100 \mathrm{~g}$ of distilled water (Dough yield $=200$ ) with $0.5 \mathrm{~g}$ strain $(\mathrm{LBr})$.

\subsection{Total Bacterial Count, $\mathrm{pH}$, and TTA and Metabolite Formation in Sourdough}

Total bacterial count (colony forming units $\mathrm{CFU} / \mathrm{mL}$ ) on the sourdough starters were analyzed using standard microbiological dilutions, plating and enumeration techniques. Briefly, $1 \mathrm{~mL}$ of sourdough starter was homogenized with $9 \mathrm{~mL}$ sterile physiological saline solution containing $0.85 \% \mathrm{NaCl}(\mathrm{w} / \mathrm{v})$, the homogenate was decimally diluted in the same solution, $1 \mathrm{~mL}$ of each dilution inoculated in MRS agar and incubated at $37^{\circ} \mathrm{C}$ for $28 \mathrm{~h} . \mathrm{pH}$ and titratable acidity (TTA) were determined on sourdough starters, doughs and breads following the previously reported method [8]. Briefly, sample aliquots (10g) were homogenized with $90 \mathrm{~mL}$ of sterile distilled water. The $\mathrm{pH}$ value was recorded, and the acidity was titrated with $0.1 \mathrm{~mol} / \mathrm{L} \mathrm{NaOH}$ to a final $\mathrm{pH}$ of 8.6. The TTA was expressed in milliliters of $0.1 \mathrm{~mol} / \mathrm{L} \mathrm{NaOH}$. To determine the concentration of organic acids and sugars, for sample preparations, $7 \%$ perchloric acid were added to sourdough and incubated at $4{ }^{\circ} \mathrm{C}$ overnight. Precipitated protein was removed by centrifugation.

Organic acids were determined by HPLC using the REZEX $8 \mu \quad 8 \% \mathrm{H}$, organic acid column $300 \times 7.8 \mathrm{mM}$ (Phenomenex, USA) coupled to a refrective index detector and UV detector $(210 \mathrm{~nm})$ were used for detection. As the elution fluid with $0.01 \mathrm{~N} \mathrm{H}_{2} \mathrm{SO}_{4}$ was used, at a flow rate of $0.6 \mathrm{~mL} / \mathrm{min}$. The temperature of the column was maintained at $65^{\circ} \mathrm{C}$. Malic acid, lactic acid, acetic acid, citric acid, succinic acid, fumaric acid and ethanol were determined using external standards. Sugars were analyzed with an Aminex $87 \mathrm{H}$ column $(300 \mathrm{~mm} * 7.8 \mathrm{~mm}$, Bio-Rad, Mississauga, Canada) at a temperature of $70^{\circ} \mathrm{C}$ and a flow rate of $0.4 \mathrm{ml} \mathrm{min}^{-1}$ with $5 \mathrm{mM} \mathrm{H}_{2} \mathrm{SO}_{4}$ as the eluent. The injection volume was $5 \mu$ l. Rhamnose, galactose and glucose were used external standards.

\subsection{Fermentation Properties of Composite Dough}

Fermentation properties were analyzed using a Rheofermentometer F3 (Chopin, Villeneuve -La - Garenne Cedex, France) recording the following parameters: maximum height of dough ( $\mathrm{Hm}[\mathrm{mm}])$, height of maximum gaseous release (H'm $[\mathrm{mm}]$ ), time to maximum dough development (T1) and coefficient of gas retention using the method described [16]. A dough piece $(250 \mathrm{~g})$ was placed in 
a movable basket of the gas meter with a $1500 \mathrm{~g}$ cylindrical weight, and the cover of the vat was fitted with an optical sensor. The test was conducted at $38^{\circ} \mathrm{C}$ for $3 \mathrm{~h}$.

\subsection{Bread Making}

Bread ingredients were added on a percent wheat flour basis (Table 2). Briefly, the bread basic recipe included $500 \mathrm{~g}$ of wheat flour, 1\% salt, 1\% baker's yeast (Saccharomyces cereviseae), sugar $3 \%$, and $5 \%$ shortening. Sorghum sourdough starter was added at $10 \% \mathrm{SSD}_{\mathrm{LP}}, 20 \% \mathrm{SSD}_{\mathrm{LP}}$, $10 \% \mathrm{SSD}_{\mathrm{LBr}}$ and $20 \% \mathrm{SSD}_{\mathrm{LBr}}$ and nabag sourdough starter at $10 \% \mathrm{NSD}_{\mathrm{LP}}, 20 \% \mathrm{NSD}_{\mathrm{LP}}, 10 \% \mathrm{NSD}_{\mathrm{LBr}}$ and $20 \% \mathrm{NSD}_{\mathrm{LBr}}$. The control consisted of $100 \%$ wheat flour bread without sorghum sourdough starter and nabag sourdough starter. Shortening was incorporated 2 min after the end of first mixing. Mixing was done in a spiral mixer (SM-25, Sinmag Bakery Equipment, Wuxi Co., Ltd., Wuxi City, Jiangsu, China) and comprising two steps. The first step consisted of $3 \mathrm{~min}$ at low speed and $3.5 \mathrm{~min}$ at high speed. The second step consisted of $0.5 \mathrm{~min}$ at low speed and $3 \mathrm{~min}$ at high speed. The dough was divided into $60 \mathrm{~g}$ round pieces. Dough pieces were proofed for $90 \mathrm{~min}$, at $35^{\circ} \mathrm{C}$ and $85 \%$ relative humidity (SM-40SP, Sinmag Bakery Equipment, Wuxi Co., Ltd., Wuxi City, Jiangsu, China) and baked at $180^{\circ} \mathrm{C}$ for about $25 \mathrm{~min}$ in an oven (SM-603T,Sinmag Bakery Equipment, Wuxi Co., Ltd., Wuxi City, Jiangsu, China). After baking, the breads were packed in plastic bags. The breads were stored at room temperature up to 7 days.

\subsection{Physical Characteristics of Breads}

Breads were evaluated for loaf weight, loaf volume (rapeseed displacement), and specific volume $(\mathrm{mL} / \mathrm{g})$ one hour after removal from the oven. The bake off expressed as percentage was calculated by recording the weight of dough and baked loaf according to the method [17].

\subsection{Shelf Life}

Standard baking tests were performed on three loaves for each bread type at each baking trial $2 \mathrm{~h}$ after baking (day 0 ) as previously described [18]. The remaining loaves were packed and further evaluation was carried out after 1, 3, 5 and 7 days of storage. Moisture content of the samples were determined according to AAC method 44-15A. Crumb texture analyses, three slices of $25 \mathrm{~mm}$ thickness were sliced from the center of each three loaves of each bread type. The textural characteristics of the bread were measured with a Texture Analyzer TA.XT2i (Stable Microsystems, Godalming, U.K.) equipped with an aluminum $25 \mathrm{~mm}$ diameter cylindrical probe. Breads were sliced using a bread slicer SM-302N (Sinmag Bakery Equipment, Wuxi Co., Ltd., Wuxi City, Jiangsu, China) set at $12.5 \mathrm{~mm}$ thick. Bread slices taken from the center of each loaf were used to evaluate the crumb texture. A stack of two slices was prepared and the top slice was compressed to $50 \%$ of its original thickness. The test conditions were: pre-test speed, $1 \mathrm{~mm} / \mathrm{sec}$; test speed, 3 $\mathrm{mm} / \mathrm{sec}$; posttest speed, $3 \mathrm{~mm} / \mathrm{sec}$; and trigger force (auto mode), $5 \mathrm{~g}$. The measurements obtained for three loaves of one batch over storage time were averaged into one value (one replicate). TPA was repeated after 1, 3, 5 and 7 days of storage at room temperature. The following parameters were recorded: hardness, gumminess, chewiness, resilience and cohesiveness.

The microbial shelf life of breads was determined using the method described [19]. Each loaf was sliced transversely in a sterile manner to obtain uniform slices of $25 \mathrm{~mm}$ thickness. Each side of the slice was exposed to air for $5 \mathrm{~min}$, packed in a plastic bag and heat sealed. A tip of a pipette was inserted to ensure comparable aerobic conditions in each bag. Bags were incubated at room temperature and examined over a 7-day storage period. Mould growth was quantified as the number of slice surfaces, i.e. both front and back of the slice, showing aerial mycelia as a percentage of total bread slices.

\subsection{Statistical Analysis}

Analysis of variance was conducted using SPSS Statistical program v. 16.0 (SPSS Inc., Chicago, USA) and mean separation by Duncan's multiple range with a significance level of $0.05 \%$. The results were reported as mean (at least in triplicates, $n=3$ ) and standard deviation for each treatment.

\section{Results and Discussion}

\subsection{Sourdough Acidification, Analysis of Fermentation Products and Sugars}

The effect of fermentation in sorghum and nabag flour by L. plantarum $(\mathrm{LP})$ and L. brevis $(\mathrm{LBr})$ on $\mathrm{pH}$ and titratable acidity (TTA) was reported in Table 1 . The $\mathrm{pH}$ of fermented sorghum and nabag flour by $L$. brevis decreased from 6.24 to 3.60 , and 5.00 to 4.07 , respectively, whiles TTA increased from 2.3 to $14.70,7.10$ to 15.50 . Similarly the $\mathrm{pH}$ for $L$. Plantarum also decreased from 6.21 to 3.50 , and 4.97 to 3.81, respectively, meanwhils, TTA increased from 2.5 to 16.9 , and 7.30 to 16.60 , respectively. L. plantarum and $L$. brevis strains are known to produce a lactic and other organic acid which survives at low $\mathrm{pH}$ [20]. The decrease in $\mathrm{pH}$ and increase in lactic acid followed the same trend as reported for other traditionally fermented foods [21]. Kinetics of sorghum and nabag sourdoughs ferment as total bacterial count with $L$. plantarum showed an increase from $6.50 \mathrm{E}+08$ to $9.40 \mathrm{E}+08$ $\mathrm{CFU} / \mathrm{mL}$ and $5.50 \mathrm{E}+08$ to $7.90 \mathrm{E}+08$ whiles L. brevis showed an increase from $5.78 \mathrm{E}+08$ to $8.50 \mathrm{E}+08,5.00 \mathrm{E}+08$ to $7.10 \mathrm{E}+08 \mathrm{CFU} / \mathrm{mL}$, respectively, reaching a maximum growth of $24 \mathrm{~h}$ (Table 1). Kinetics of sorghum and nabag sourdough ferment as total bacterial count with L. plantarum was higher than L. brevis, suggesting that the sorghum and nabag flour was better for L. plantarum than L. brevis. The levels of organic acids and sugars in sorghum and nabag sourdoughs were reported after $24 \mathrm{~h}$ fermentation in (Table 1). The predominant acids and sugars in sorghum and nabag sourdoughs fermented with L. plantarum and L. brevis are malic acid, lactic acid, acetic acid, citric acid, succinic acid, fumaric acid, ethanol, arabinose, galactose and glucose are 
shown in (Table 1). Fermented sorghum and nabag sourdoughs by $L$. plantarum exhibited different concentrations of organic acids in sorghum sourdough; malic acid $0.105 \mathrm{~g} / 100 \mathrm{~mL}$, lactic acid $0.573 \mathrm{~g} / 100 \mathrm{~mL}$, acetic acid $0.107 \mathrm{~g} / 100 \mathrm{~mL}$, citric acid $0.001 \mathrm{~g} / 100 \mathrm{~mL}$, succinic acid $0.0026 \mathrm{~g} / 100 \mathrm{~mL}$ and fumaric acid $0.003 \mathrm{~g} / 100 \mathrm{~mL}$, while in nabag sourdough $(0.060 \mathrm{~g} / 100 \mathrm{~mL}, \quad 0.282 \mathrm{~g} / 100 \mathrm{~mL}$, $0.026 \mathrm{~g} / 100 \mathrm{~mL}, \quad 0.012 \mathrm{~g} / 100 \mathrm{~mL}, \quad 0.019 \mathrm{~g} / 100 \mathrm{~mL} \quad$ and $0.002 \mathrm{~g} / 100 \mathrm{~mL})$, respectively. Malic acid, lactic acid, acetic acid, succinic acid and fumaric acid were in higher amounts in sorghum sourdough compared to nabag sourdough, but citric acid was higher in nabag sourdough compared to sorghum sourdough. Fermented sorghum and nabag flour by L. brevis in sorghum sourdough were: malic acid $0.175 \mathrm{~g} / 100 \mathrm{~mL}$, lactic acid $0.099 \mathrm{~g} / 100 \mathrm{~mL}$, acetic acid $0.033 \mathrm{~g} / 100 \mathrm{~mL}$, citric acid $0.063 \mathrm{~g} / 100 \mathrm{~mL}$, succinic acid $0.005 \mathrm{~g} / 100 \mathrm{~mL}$ and fumaric acid $0.002 \mathrm{~g} / 100 \mathrm{~mL}$, while in nabag sourdough $\quad 0.068 \mathrm{~g} / 100 \mathrm{~mL}, \quad 0.048 \mathrm{~g} / 100 \mathrm{~mL}$, $0.033 \mathrm{~g} / 100 \mathrm{~mL}, \quad 0.0117 \mathrm{~g} / 100 \mathrm{~mL}, \quad 0.001 \mathrm{~g} / 100 \mathrm{~mL} \quad$ and $0.001 \mathrm{~g} / 100 \mathrm{~mL}$, respectively. Comparatively, lower amount of malic acid, lactic acid, acetic acid and fumaric acid were found in nabag sourdough but succinic acid was higher. Higher concentration of ethanol $(0.037 \mathrm{~g} / 100 \mathrm{~mL})$ was found in $\mathrm{NSD}_{\mathrm{LBr}}$ but lower volumes were recorded in $\mathrm{SSD}_{\mathrm{LBr}}$ $(0.012 \mathrm{~g} / 100 \mathrm{~mL})$. No ethanol was detecetd in $\mathrm{SSD}_{\mathrm{LP}}$ and

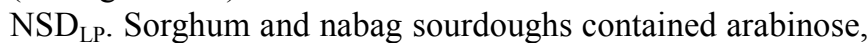
galactose and glucose. Fermented sorghum and nabag flour by $L$. Plantarum in sorghum and nabag sourdoughs contains arabinose $0.433 \mathrm{mg} / \mathrm{L}, \quad 0.311 \mathrm{mg} / \mathrm{L}$, galactose $2.286 \mathrm{mg} / \mathrm{L}$, 148.786 and glucose $2.698 \mathrm{mg} / \mathrm{L}$, while by those L. brevis had arabinose $0.369 \mathrm{mg} / \mathrm{L}, 0.294 \mathrm{mg} / \mathrm{L}$ and galactose $0.139 \mathrm{mg} / \mathrm{L}$, $27.866 \mathrm{mg} / \mathrm{L}$, respectively. Higher amount of galactose in $\mathrm{NSD}_{\mathrm{LP}}$ and $\mathrm{NSD}_{\mathrm{LBr}}$ whiles lower amounts of arabinose and glucose were detected in $\mathrm{SSD}_{\mathrm{LP}}$.

Table 1. pH, TTA, Total bacteria count, orgnic acids and sugars in sour doughs after24h fermentation.

\begin{tabular}{|c|c|c|c|c|}
\hline & $\mathbf{S S D}_{\mathrm{LP}}{ }^{\mathrm{b}}$ & $\operatorname{NSD}_{L P}{ }^{c}$ & $\operatorname{SSD}_{\mathrm{LBr}}{ }^{\mathrm{d}}$ & $\mathrm{NSD}_{\mathrm{LBr}}{ }^{\mathrm{e}}$ \\
\hline $\mathrm{pH}$ & $3.50 \pm 0.01^{\mathrm{a}}$ & $3.81 \pm 0.01^{\mathrm{d}}$ & $3.60 \pm 0.02^{\mathrm{b}}$ & $4.70 \pm 0.01^{\mathrm{c}}$ \\
\hline $\mathrm{TTA} / \mathrm{mL}$ & $16.9 \pm 0.00^{\mathrm{a}}$ & $16.60 \pm 0.01^{\mathrm{b}}$ & $14.70 \pm 0.01^{\mathrm{d}}$ & $15.50 \pm 0.01^{\mathrm{c}}$ \\
\hline $\mathrm{CFU} / \mathrm{mL}$ & $9.40 \mathrm{E}+08$ & $7.90 \mathrm{E}+08$ & $8.50 \mathrm{E}+08$ & $7.10 \mathrm{E}+08$ \\
\hline Malic Acid (g/100mL) & $0.108 \pm 0.001^{\mathrm{b}}$ & $0.060 \pm 0.003^{\mathrm{d}}$ & $0.175 \pm 0.001^{\mathrm{a}}$ & $0.068 \pm 0.001^{\mathrm{c}}$ \\
\hline Lactic Acid (g/100mL) & $0.573 \pm 0.001^{\mathrm{a}}$ & $0.282 \pm 0.002^{\mathrm{b}}$ & $0.099 \pm 0.000^{c}$ & $0.048 \pm 0.001^{\mathrm{d}}$ \\
\hline Acetic Acid (g/100mL) & $0.107 \pm 0.002^{\mathrm{a}}$ & $0.026 \pm 0.001^{\mathrm{c}}$ & $0.033 \pm 0.002^{b}$ & $0.033 \pm 0.002^{b}$ \\
\hline Citric Acid (g/100mL) & $0.010 \pm 0.003^{\mathrm{c}}$ & $0.012 \pm 0.002^{b}$ & $0.063 \pm 0.001^{\mathrm{a}}$ & $0.012 \pm 0.002^{\mathrm{b}}$ \\
\hline Fumaric Acid (g/100mL) & $0.003 \pm 0.001^{\mathrm{a}}$ & $0.002 \pm 0.001^{\mathrm{b}}$ & $0.002 \pm 0.001^{b}$ & $0.001 \pm 0.001^{\mathrm{c}}$ \\
\hline Ethanol $(\mathrm{g} / 100 \mathrm{~mL})$ & nd & nd & $0.012 \pm 0.002^{b}$ & $0.037 \pm 0.001^{\mathrm{a}}$ \\
\hline Arabinose (mg/L) & $0.433 \pm 0.001^{\mathrm{a}}$ & $0.320 \pm 0.002^{\mathrm{c}}$ & $0.369 \pm 0.000^{b}$ & $0.294 \pm 0.001^{\mathrm{d}}$ \\
\hline Galactose (mg/L) & $2.286 \pm 0.001^{\mathrm{c}}$ & $148.786 \pm 0.001^{\mathrm{a}}$ & $0.139 \pm 0.000^{\mathrm{d}}$ & $27.866 \pm 0.001^{\mathrm{b}}$ \\
\hline Glucose (mg/L) & $2.698 \pm 0.001^{\mathrm{a}}$ & nd & nd & nd \\
\hline
\end{tabular}

${ }^{\mathrm{a}}$ Data are means \pm standard deviations of two independent experiments.

${ }^{\mathrm{b}} \mathrm{SSD}_{\mathrm{LP}}$, Sorghum sourdough fermented by Lactobacillus plantarum (LP).

${ }^{\mathrm{c}} \mathrm{NSD}_{\mathrm{LP}}$, Nabag sourdough fermented by Lactobacillus plantarum (LP).

${ }^{\mathrm{d}} \mathrm{SSD}_{\mathrm{LBr}}$, Sorghum sourdough fermented by Lactobacillus brevis ( $\left.\mathrm{LBr}\right)$.

${ }^{\mathrm{e}} \mathrm{NSD}_{\mathrm{LBr}}$, Nabag sourdough fermented by Lactobacillus brevis ( $\left.\mathrm{LBr}\right)$.

nd-not detected

Table 2. Formula of breads containing sorghum sourdough starters and nabag sourdough starters

\begin{tabular}{|c|c|c|c|c|c|c|c|c|c|c|c|}
\hline ID $^{\mathbf{a}}$ & SD*Addition (\%) & Flour (g) & Water (g) & Salt (g) & Yeast (g) & Sugar (g) & Shortening(g) & SSD $_{\mathrm{LBr}}$ & SSD $_{\mathrm{LP}}$ & $\mathrm{NSD}_{\mathrm{LBr}}$ & $\mathbf{N S D}_{\mathrm{LP}}$ \\
\hline $\mathrm{T}_{1}$ & 0 & 500 & 300 & 5 & 5 & 15 & 25 & 0 & 0 & 0 & 0 \\
\hline $\mathrm{T}_{2}$ & 10 & 450 & 260 & 5 & 5 & 15 & 25 & 50 & 0 & 0 & 0 \\
\hline $\mathrm{T}_{3}$ & 20 & 400 & 235 & 5 & 5 & 15 & 25 & 100 & 0 & 0 & 0 \\
\hline $\mathrm{T}_{4}$ & 10 & 450 & 260 & 5 & 5 & 15 & 25 & 0 & 0 & 50 & 0 \\
\hline $\mathrm{T}_{5}$ & 20 & 400 & 235 & 5 & 5 & 15 & 25 & 0 & 0 & 100 & 0 \\
\hline $\mathrm{T}_{6}$ & 10 & 450 & 240 & 5 & 5 & 15 & 25 & 0 & 50 & 0 & 0 \\
\hline $\mathrm{T}_{7}$ & 20 & 400 & 220 & 5 & 5 & 15 & 25 & 0 & 100 & 0 & 0 \\
\hline $\mathrm{T}_{9}$ & 20 & 400 & 220 & 5 & 5 & 15 & 25 & 0 & 0 & 0 & 100 \\
\hline
\end{tabular}

$\mathrm{ID}^{\mathrm{a}}$, Treatment identification.

$\mathrm{SD}^{*}$, Sourdough.

$\mathrm{SSD}_{\mathrm{LBr}}$, Sorghum sourdough fermented by Lactobacillus brevis ( $\left.\mathrm{LBr}\right)$.

$\mathrm{SSD}_{\mathrm{LP}}$, Sorghum sourdough fermented by Lactobacillus plantarum (LP).

$\mathrm{NSD}_{\mathrm{LBr}}$, Nabag sourdough fermented by Lactobacillus brevis ( $\left.\mathrm{LBr}\right)$.

$\mathrm{NSD}_{\mathrm{LP}}$, Nabag sourdough fermented by Lactobacillus plantarum (LP).

\subsection{Fermentation Properties of Dough}

Sorghum and nabag sourdoughs affected significantly $(\mathrm{P} \leq 0.05)$ dough fermentation properties are summarized in
(Table 3). The addition of $10 \% \mathrm{SD}_{\mathrm{LBr}}$ increase $(\mathrm{P}<0.05)$ of a maximum dough development $(\mathrm{Hm})$ with two treatments $\mathrm{T} 2$ $(83.7 \mathrm{~mm})$ and $\mathrm{T} 4(84.1 \mathrm{~mm}),(\mathrm{T} 290 \%$ wheat flour and $10 \%$ $\mathrm{SSD}_{\mathrm{LBr}}$; $\mathrm{T} 490 \%$ wheat flour and $10 \% \mathrm{NSD}_{\mathrm{LBr}}$ ) compared 
with a control $\mathrm{T} 1(79.2 \mathrm{~mm})$, but was a decreased upon the addition of $20 \% \mathrm{SD}_{\mathrm{LBr}}, \mathrm{T} 3(64.7 \mathrm{~mm})$ and $\mathrm{T} 5(67.7 \mathrm{~mm})$. The decrease of $\mathrm{Hm}$ with increasing SD was attributed mainly to the dilution of gluten. The addition of $\mathrm{SD}_{\mathrm{LP}}$ increase $(\mathrm{P}<0.05)$ to a maximum dough development $(\mathrm{Hm})$ with three treatments T6, T7 and T8 (T6 90\% wheat flour and 10\% $\mathrm{SSD}_{\mathrm{LP}}$; $\mathrm{T} 7\left(80 \%\right.$ wheat flour and $\left.20 \% \mathrm{SSD}_{\mathrm{LP}}\right)$ and $\mathrm{T} 8(90 \%$ wheat flour and $\left.10 \% \mathrm{NSD}_{\mathrm{LP}}\right) 83.8,83.8$ and $84.4 \mathrm{~mm}$, respectively, decreased T9 $(80 \%$ wheat flour and $20 \%$ $\left.\mathrm{NSD}_{\mathrm{LP}}\right) \quad 76.8 \pm 0.3 \mathrm{~mm}$, compared with the control. Hm compared to sorghum sourdough starters were lower with the nabag sourdough starters. Overall, sorghum sourdough and nabag sourdough also reduced the time of development of maximum dough height (T1). The levels of gas produced increased; indicating the presence of gas (increased H'm) but the dough did not retain it (decrease in $\mathrm{Hm}$ ). There was a significant increase $(\mathrm{P}<0.05)$ in the overall effect of the treatments on total gas volume and gas retention volume compared to the control (Table 3). Total gas volume and gas retention volume were improved by the addition of more sorghum sourdough and nabag sourdoughs indicating that there was no lack of gas produced. The results could be partially explained by increased gas production by active LAB in the sorghum and nabag sourdoughs. Gas retention ratio (R3) decreased with the treatments compared to the control (Table 3) suggesting that the dough prevented gas release efficiently. In conclusion, the addition of sorghum sourdough and nabag sourdough in the dough ehnaced maximum gas fermentation height, total gas volume and gas retention volume whiles improving the fermentation properties of the dough when combined with the LAB fermentation.

Table 3. Effect of addition sorghum sourdough starters and nabag sourdough starters on Fermentation Properties obtained with a Rheofermentometer F3.

\begin{tabular}{|c|c|c|c|c|c|c|}
\hline Samples $^{\text {b }}$ & $\mathrm{Hm}^{\mathrm{c}}(\mathrm{mm})$ & $T 1^{\mathrm{d}}$ (min) & $H^{\prime} m^{\mathrm{e}}(\mathbf{m m})$ & $\mathrm{R1}^{\mathrm{f}}(\mathrm{ml})$ & $\mathbf{R} 2^{\mathrm{g}}(\mathrm{ml})$ & $\mathrm{R3}^{\mathrm{h}} \%$ \\
\hline $\mathrm{T}_{1}$ & $79.2 \pm 1.13^{\mathrm{e}}$ & $180 \pm 0.0^{\mathrm{a}}$ & $62.1 \pm 0.4^{\mathrm{g}}$ & $1265 \pm 15.13^{\mathrm{i}}$ & $1263 \pm 14.10^{\mathrm{i}}$ & $99.9 \pm 0.00^{\mathrm{a}}$ \\
\hline $\mathrm{T}_{2}$ & $83.7 \pm 0.1^{\mathrm{cd}}$ & $120 \pm 0.1^{\mathrm{b}}$ & $83.9 \pm 0.1^{\mathrm{f}}$ & $1791 \pm 14.77^{\mathrm{h}}$ & $1729 \pm 7.12^{\mathrm{h}}$ & $96.5 \pm 0.01^{\mathrm{f}}$ \\
\hline $\mathrm{T}_{3}$ & $64.7 \pm 0.4^{\mathrm{h}}$ & $120 \pm 0.1^{b}$ & $90.2 \pm 0.5^{\mathrm{c}}$ & $1955 \pm 17.16^{\mathrm{e}}$ & $1910 \pm 6.33^{c}$ & $97.7 \pm 0.07^{b}$ \\
\hline $\mathrm{T}_{4}$ & $84.1 \pm 0.1^{\mathrm{ab}}$ & $120 \pm 0.1^{b}$ & $90.2 \pm 0.5^{\mathrm{c}}$ & $1964 \pm 17.79^{\mathrm{d}}$ & $1886 \pm 7.10^{\mathrm{d}}$ & $96.0 \pm 0.01^{\mathrm{h}}$ \\
\hline $\mathrm{T}_{5}$ & $67.7 \pm 0.4^{\mathrm{g}}$ & $120 \pm 0.2^{\mathrm{b}}$ & $89.9 \pm 0.1^{\mathrm{d}}$ & $1984 \pm 17.79^{b}$ & $1937 \pm 6.00^{b}$ & $97.5 \pm 0.07^{d}$ \\
\hline $\mathrm{T}_{6}$ & $83.8 \pm 0.1^{\mathrm{c}}$ & $120 \pm 0.1^{\mathrm{b}}$ & $92.1 \pm 0.8^{\mathrm{b}}$ & $1979 \pm 17.77^{\mathrm{c}}$ & $1857 \pm 7.00^{f}$ & $93.1 \pm 0.30^{\mathrm{i}}$ \\
\hline $\mathrm{T}_{7}$ & $83.8 \pm 0.2^{c}$ & $120 \pm 0.1^{b}$ & $100.5 \pm 0.2^{\mathrm{a}}$ & $2094 \pm 12.00^{\mathrm{a}}$ & $2044 \pm 14.00^{\mathrm{a}}$ & $97.6 \pm 0.07^{c}$ \\
\hline $\mathrm{T}_{9}$ & $76.8 \pm 0.3^{f}$ & $120 \pm 0.2^{\mathrm{b}}$ & $86.0 \pm 0.4^{\mathrm{e}}$ & $1892 \pm 14.79^{g}$ & $1826 \pm 2.10^{\mathrm{g}}$ & $96.6 \pm 0.01^{\mathrm{e}}$ \\
\hline
\end{tabular}

${ }^{\mathrm{a}}$ Mean values $(\mathrm{n}=3) \pm$ standard deviation within a column followed by different letter superscript are significantly different $(\mathrm{P} \leq 0.05)$.

${ }^{\mathrm{b}}$ Treatments as described in Table 2 .

${ }^{\mathrm{c}} \mathrm{Hm}$, Maximum dough fermentation height.

${ }^{\mathrm{d}} \mathrm{T} 1$, Final dough fermentation.

${ }^{\mathrm{e}} \mathrm{H}$ 'm, Maximum gas fermentation height.

${ }^{\mathrm{f}} \mathrm{R} 1$, Total gas volume.

${ }^{\mathrm{g}} \mathrm{R} 2$, Retention volume.

${ }^{\mathrm{h}} \mathrm{R} 3$, Retention coefficient.

\subsection{Physical Characteristics of Breads}

Addition of sorghum and nabag sourdoughs starters in breads ensured higher specific volumes and improved the overall texture when compared to the control (non-sourdough treatment) (Table $4 \mathrm{a}$ ) indicating that LAB starters improved the form ratio of bread. These results were similar to those reported [19, 22] who reported that breads with higher specific volume values had softer crumb texture. However, there are combined reports in the literature on sourdough fermentation and its effect on bread specific volume. The specific volume of bread appears to be highly dependent on the type and level of acidification [23]. The positive effect of sourdough in bread volume has been associated with improved gas holding capacity of the dough [24]. The highest bread SV $(6.20 \pm 0.1 \mathrm{~g} / \mathrm{mL})$ was obtained with $20 \%$ nabag sourdough with LP (T9) compared to control. Addition of nabag sourdough starters in breads ensures higher specific volume compared to sorghum sourdough starters (Table 4a). This means nabag sourdough starters improved the form ratio of the breads compared to the sorghum sourdough starters. The loaf volume of the bread was significantly improved $(\mathrm{p}<0.05)$ through the addition of sorghum and nabag sourdough starters, with the exception T6 (T6 90\% wheat flour and $10 \%$ sorghum sourdough starters with LP) which is similar to the control. The nabag sourdough starters improved gluten gave the bread its structural framework; indicating that gluten is needed to improve the loaf volume of breads in practical applications. The results obtained by addition of nabag sourdough starters gave the breads the positive baking characteristics; meanwhile, the weight of the bread is reduced during this transformation. The results presented in (Table 4) indicate that (T4 10\% nabag sourdough starters with $\mathrm{LBr}$ ) had the lowest ratio loss value $(12.7 \%)$, compared with the other samples, which ranged from (18.3 to $12.7 \%$ ), resulting in the lowest loss ratio value by the addition of $10 \%, 20 \%$ nabag sourdough starters compared with the addition of $10 \%, 20 \%$ sorghum sourdough starters. These data suggest that nabag sourdough starters can be substituted to improve the loaf volume, and loaf height of composite flour bread.

\section{4. pH and Titratable Acidity of Dough and Breads}

Incorporation of sorghum and nabag sourdough starters into bread making process resulted in a decrease in $\mathrm{pH}$ and 
an increase of TTA values compared to the control (Table 4b). In mixed doughs, proofed doughs and breads, increasing the amounts of sorghum and nabag starters led to a progressive decrease of $\mathrm{pH}$ and increased TTA values compared to the non-acidified control mixed doughs, proofed doughs and breads. The $\mathrm{pH}$ decrease in mixed doughs, proofed doughs and breads from 5.54, 5.36 and 5.44 (control) to $4.74,4.24$ and 4.14 (T9: $20 \%$ nabag sourdough starter with LP) with an increase in titratable acidity from $3.91,3.98$ and $3.85 \mathrm{~mL}$ (control) to $8.35,9.69$ and $8.90 \mathrm{~mL}$ (T9 20\% nabag sourdough starter with LP). Breads produced with addition of nabag sourdough starters showed higher TTA values and lower $\mathrm{pH}$ values in comparison to the addition of sorghum sourdough starters. The results of the present study indicate that fermented nabag with LP is needed to obtain some of the $\mathrm{pH}$ and titratable acidity of the breads. The drop in $\mathrm{pH}$ associated with acid production could cause an increase as the activity of proteases and amylases in the dough, thus leading to a reduction in staling [25] with subsequent extension of shelf-life [19]. Among other benefits from sourdough fermentation is antimicrobial activity as a result of low $\mathrm{pH}$ and antibacterial compounds produced by LAB.

Table 4a. Effect of addition sorghum sourdough staters and nabag sourdough staters on baking characteristics of breads.

\begin{tabular}{lllll}
\hline Sample $^{\text {b }}$ & Weight $(\mathbf{g})$ & Volume $(\mathbf{m l})$ & SV. $^{\mathbf{c}}(\mathbf{m l} / \mathbf{g})$ & Bake off (\%) \\
\hline $\mathrm{T}_{1}$ & $51.2 \pm 0.1^{\text {bcd }}$ & $250 \pm 3.1^{\mathrm{j}}$ & $4.88 \pm 0.0^{\mathrm{i}}$ & $14.7 \pm 0.02^{\text {ef }}$ \\
$\mathrm{T}_{2}$ & $49.8 \pm 0.1^{\mathrm{e}}$ & $260 \pm 5.9^{\mathrm{f}}$ & $5.22 \pm 0.1^{\mathrm{f}}$ & $17.0 \pm 0.05^{\mathrm{cd}}$ \\
$\mathrm{T}_{3}$ & $51.4 \pm 0.1^{\mathrm{bc}}$ & $255 \pm 6.2^{\mathrm{i}}$ & $4.96 \pm 0.0^{\mathrm{h}}$ & $14.3 \pm 0.01^{\mathrm{fg}}$ \\
$\mathrm{T}_{4}$ & $52.4 \pm 0.1^{\mathrm{a}}$ & $315 \pm 0.0^{\mathrm{a}}$ & $6.01 \pm 0.1^{\mathrm{b}}$ & $12.7 \pm 0.03^{\mathrm{i}}$ \\
$\mathrm{T}_{5}$ & $51.8 \pm 0.0^{\mathrm{b}}$ & $300 \pm 0.0^{\mathrm{c}}$ & $5.79 \pm 0.0^{\text {cd }}$ & $13.7 \pm 0.02^{\text {gh }}$ \\
$\mathrm{T}_{6}$ & $49.6 \pm 0.2^{\text {ef }}$ & $250 \pm 3.1^{\mathrm{j}}$ & $5.04 \pm 0.1^{\mathrm{g}}$ & $17.3 \pm 0.00^{\mathrm{c}}$ \\
$\mathrm{T}_{7}$ & $49.0 \pm 0.1^{\text {gh }}$ & $285 \pm 1.1^{\mathrm{e}}$ & $5.82 \pm 0.0^{\mathrm{c}}$ & $18.3 \pm 0.01^{\mathrm{a}}$ \\
$\mathrm{T}_{8}$ & $50.8 \pm 0.0^{\mathrm{e}}$ & $290 \pm 2.8^{\mathrm{d}}$ & $5.72 \pm 0.0^{\mathrm{e}}$ & $15.3 \pm 0.04^{\mathrm{e}}$ \\
$\mathrm{T}_{9}$ & $49.20 \pm 0.0^{\text {efg }}$ & $305 \pm 3.3^{\mathrm{b}}$ & $6.20 \pm 0.1^{\mathrm{a}}$ & $18.0 \pm 0.00^{\mathrm{ab}}$ \\
\hline
\end{tabular}

${ }^{a}$ Mean values $(n=3) \pm$ standard deviation within a column followed by different letter superscript are significantly different $(\mathrm{P} \leq 0.05)$.

${ }^{\mathrm{b}}$ Treatments as described in Table 2.

${ }^{\mathrm{c}} \mathrm{SV}$. specific volume.

Table 4b. Effect of sorghum sourdough starters and nabag sourdough starters on pH and titratable acidity (TTA) of dough and breads.

\begin{tabular}{|c|c|c|c|c|c|c|}
\hline Sample ${ }^{\mathrm{b}}$ & Mixed dough & & Proofed do & & Bread & \\
\hline & pH & TTA $/ \mathbf{c} L$ & pH & TTA/mL & $\mathrm{pH}$ & TTA/mL \\
\hline $\mathrm{T}_{1}$ & $5.64 \pm 0.01^{\mathrm{a}}$ & $3.91 \pm 0.03^{\mathrm{i}}$ & $5.36 \pm 0.01^{\mathrm{a}}$ & $3.98 \pm 0.03^{\mathrm{i}}$ & $5.44 \pm 0.01^{\mathrm{a}}$ & $3.85 \pm 0.07^{\mathrm{i}}$ \\
\hline $\mathrm{T}_{2}$ & $5.03 \pm 0.01^{\mathrm{c}}$ & $4.31 \pm 0.01^{\mathrm{h}}$ & $4.87 \pm 0.01^{\mathrm{b}}$ & $4.44 \pm 0.05^{\mathrm{h}}$ & $4.92 \pm 0.01^{b}$ & $4.25 \pm 0.07^{\mathrm{h}}$ \\
\hline $\mathrm{T}_{3}$ & $4.86 \pm 0.01^{\mathrm{e}}$ & $5.52 \pm 0.01^{\mathrm{e}}$ & $4.67 \pm 0.01^{\mathrm{d}}$ & $5.79 \pm 0.01^{\mathrm{f}}$ & $4.73 \pm 0.01^{\mathrm{d}}$ & $5.55 \pm 0.07^{\mathrm{f}}$ \\
\hline $\mathrm{T}_{4}$ & $4.79 \pm 0.01^{\mathrm{f}}$ & $5.29 \pm 0.01^{\mathrm{g}}$ & $4.58 \pm 0.01^{\mathrm{e}}$ & $5.37 \pm 0.07^{\mathrm{g}}$ & $4.58 \pm 0.01^{\mathrm{f}}$ & $5.05 \pm 0.07^{\mathrm{g}}$ \\
\hline $\mathrm{T}_{5}$ & $4.76 \pm 0.01^{\mathrm{fg}}$ & $5.50 \pm 0.02^{\mathrm{ef}}$ & $4.48 \pm 0.01^{\mathrm{f}}$ & $5.89 \pm 0.01^{\mathrm{e}}$ & $4.55 \pm 0.01^{\mathrm{g}}$ & $5.65 \pm 0.07^{\mathrm{e}}$ \\
\hline $\mathrm{T}_{6}$ & $5.10 \pm 0.01^{\mathrm{b}}$ & $7.20 \pm 0.02^{\mathrm{cd}}$ & $4.77 \pm 0.01^{\mathrm{c}}$ & $7.77 \pm 0.03^{\mathrm{cd}}$ & $4.81 \pm 0.01^{\mathrm{c}}$ & $7.45 \pm 0.04^{\mathrm{d}}$ \\
\hline $\mathrm{T}_{8}$ & $4.96 \pm 0.02^{\mathrm{d}}$ & $7.26 \pm 0.02^{\mathrm{c}}$ & $4.58 \pm 0.02^{\mathrm{e}}$ & $7.81 \pm 0.01^{\mathrm{c}}$ & $4.63 \pm 0.01^{\mathrm{e}}$ & $7.47 \pm 0.01^{c}$ \\
\hline $\mathrm{T}_{9}$ & $4.74 \pm 0.01^{\mathrm{gh}}$ & $8.35 \pm 0.04^{\mathrm{a}}$ & $4.24 \pm 0.02^{\mathrm{h}}$ & $9.69 \pm 0.01^{\mathrm{a}}$ & $4.41 \pm 0.02^{\mathrm{i}}$ & $8.90 \pm 0.05^{\mathrm{a}}$ \\
\hline
\end{tabular}

${ }^{a}$ Mean values $(\mathrm{n}=3) \pm$ standard deviation within a column followed by different letter superscript are significantly different (P $\left.\leq 0.05\right)$.

${ }^{\mathrm{b}}$ Treatments as described in Table 2 .

${ }^{\mathrm{C}} \mathrm{TTA}$ is reported as $\mathrm{mL} \mathrm{NaOH}(0.1 \mathrm{~N}) / 10 \mathrm{~g}$ bread dough or bread.

\subsection{Bread Shelf Life}

Moisture content is a critical factor that affects bread quality, consumer acceptance and shelf life [25]. Addition of sorghum and nabag sourdough starters in breads ensures higher moisture content compared to control non-sourdough treated (Fig. 1A). In this respect several authors have reported beneficial effects of biological acidification on bread staling [26] due to the metabolite products of fermentation [27] and in particular due to proteolytic activity of LAB [26, 28]. Moreover, the differences in moisture content between samples during storage may also substantiate these results. In fresh bread (day 0 of storage), the highest moisture content crumb in bread was obtained with $20 \% \mathrm{NSD}_{\mathrm{LP}}$ (T9) $(47.11 \pm 0.01 \%)$ compared to control $(42.77 \pm 0.01 \%)$. Addition of nabag sourdough starters in breads ensured higher moisture content compared to the sorghum sourdough starters (Fig. 1A). This means nabag sourdough starters impacted the moisture content of the breads compared to the sorghum sourdough starters and control. In general, high bread water content has been reported to increase shelf life and delay starch retrogradation [26]. The moisture content of bread samples during storage time is reported in Fig. 1A. For sample T9 (80\% wheat flour and $\left.20 \% \quad \mathrm{NSD}_{\mathrm{LP}}\right)$ higher moisture content in bread during storage compared to a control, and also higher compared other samples as shown in (Fig. 1A). Strain type has a significant effect on moisture content at all times during storage and sourdough starters with LP samples always showed a higher moisture compared sourdough starters with $\mathrm{LBr}$. The production of organic acids [26], bacterial hydrolysis of starch and proteolysis of gluten subunits [26] are activities involved in bread staling which may explain the different effects of LAB starters. Indeed, sample T9 (80\% wheat flour and $\left.20 \% \mathrm{NSD}_{\mathrm{LP}}\right)$ showed a constant moisture content whereas other samples a decrease in moisture content was observed after the first days of storage. As reported [26], moisture redistribution throughout the loaf during storage has an effect on bread freshness. The results presented in (Fig. 1B) indicate that (T9 80\% wheat flour and $20 \% \mathrm{NSD}_{\mathrm{LP}}$ ) had the lowest ratio loss values to moisture, compared with the control during storage and higher ratio loss in $\mathrm{T} 2$ (T2 $90 \%$ wheat flour and $10 \%$ $\mathrm{SSD}_{\mathrm{LBr}}$ ), T3 (T3 80\% wheat flour and $20 \mathrm{SSD}_{\mathrm{LBr}}$ ), T6 (T6: $90 \%$ wheat flour and $10 \% \mathrm{SSD}_{\mathrm{LBr}}$ ) and $\mathrm{T} 7$ (T7 80\% wheat flour and $20 \% \mathrm{SSD}_{\mathrm{LP}}$ ), resulted in the lowest ratio loss value; 
addition $10 \%, 20 \%$ nabag sourdough starters compared with the addition $10 \%, 20 \%$ sorghum sourdough starters. These data suggest that, addition of nabag sourdough starters can improve the shelf life of breads.
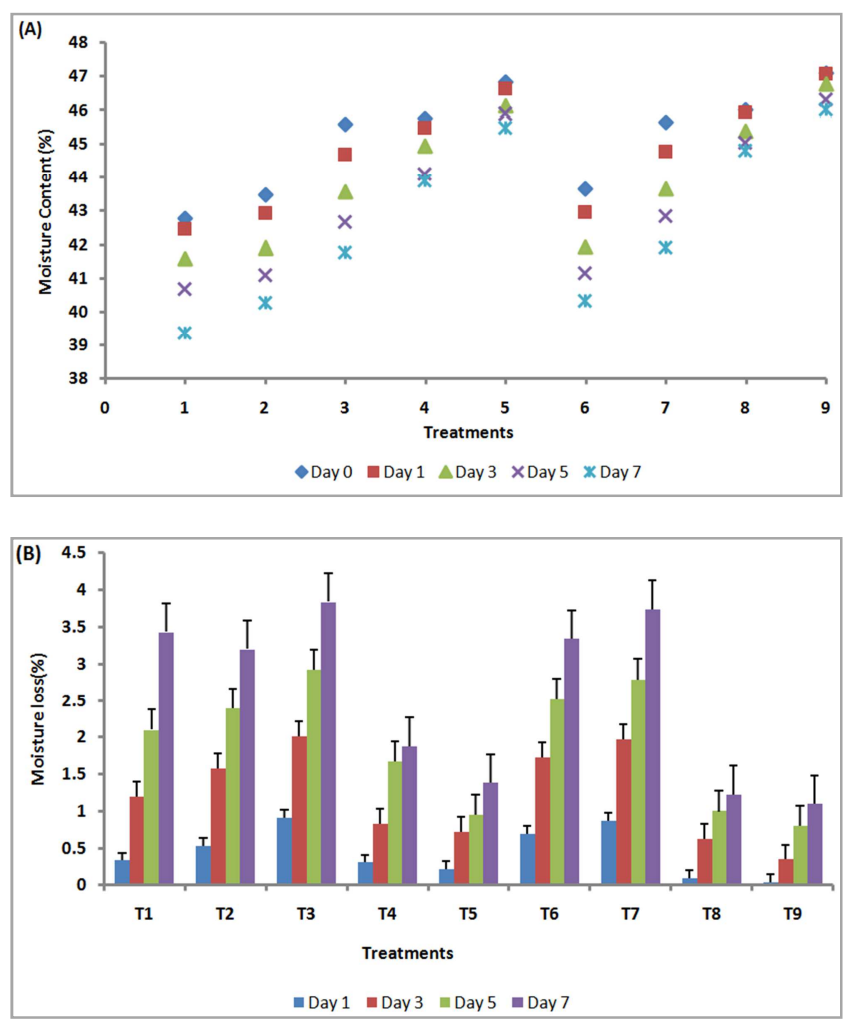

Fig. 1. Effect of addition sorghum sourdough starters and nabag sourdough starters on the moisture content (A) and moisture loss (B) for the treatments (Table 2) over 7 daysofstorage $(0,1,3,5$ and 7 days). Values are the averages of triplicates and error bars represent standard deviation.
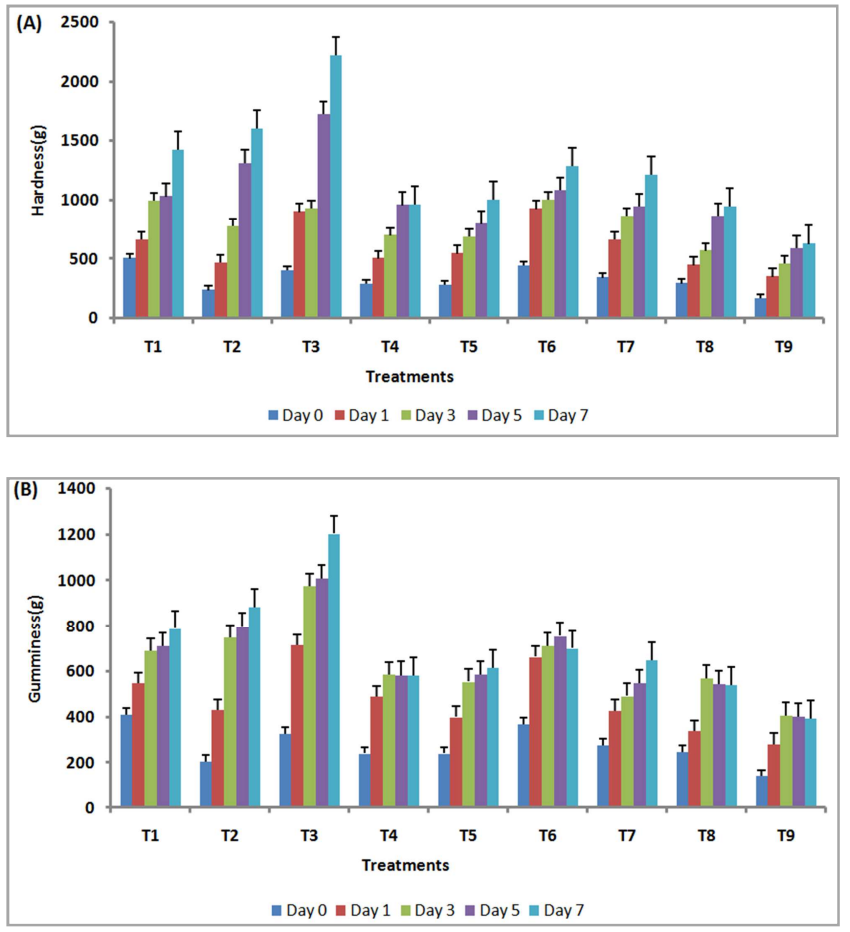
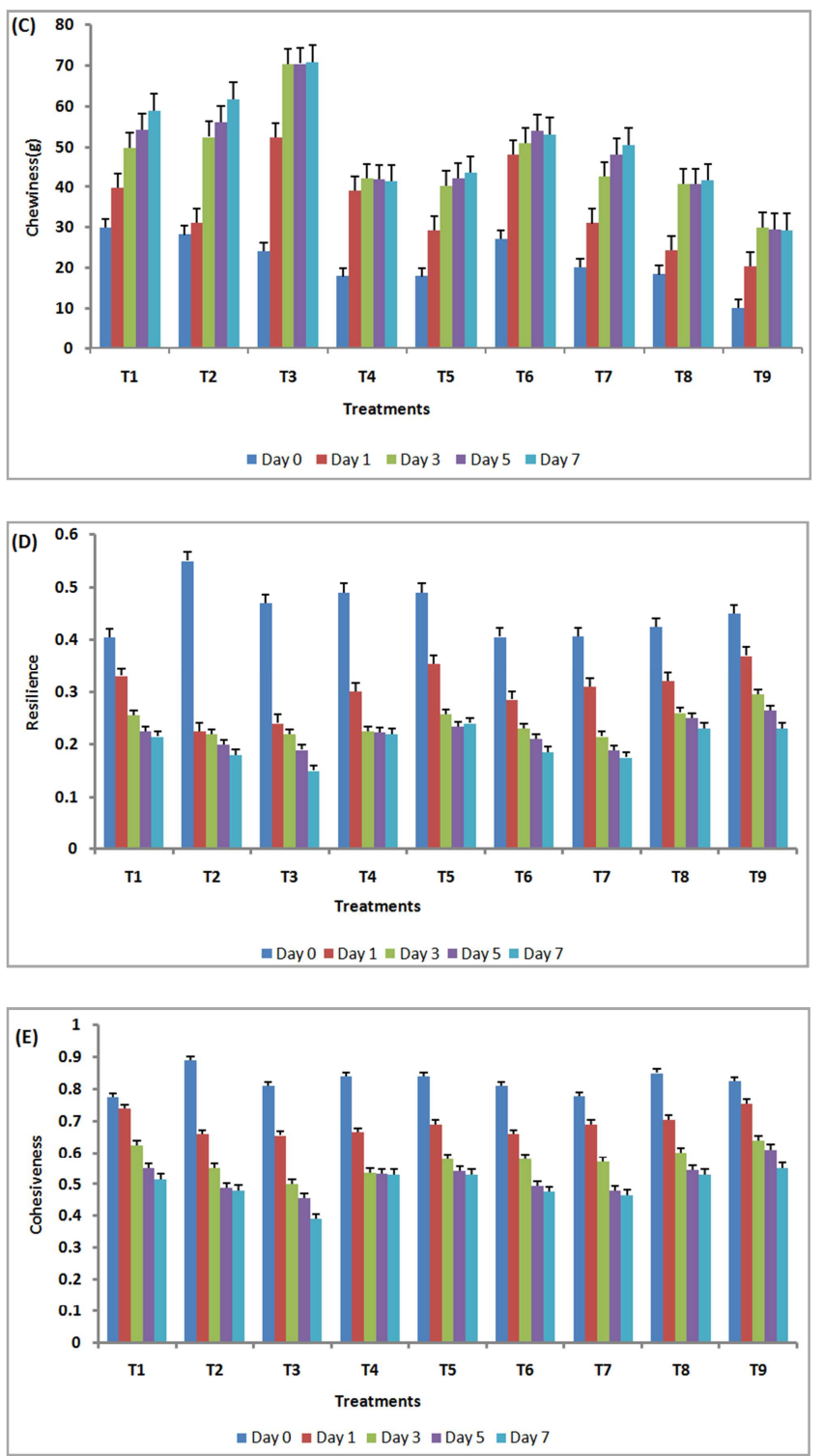

Fig. 2. Effect of addition sorghum sourdough starters and nabag sourdough starters on hardness $(A)$, gumminess $(B)$, chewiness $(C)$, resilines $(D)$ and cohesiveness (E) for the treatments (Table 2) over 7 days of storage (0, 1, 3, 5 and 7 days). Values are the averages of triplicates and error bars represent standard deviation.

Hardness and gumminess of bread samples during storage time is reported in (Fig. 2). In fresh bread (0 day of storage), addition of sorghum and nabag sourdough starters decreased $(\mathrm{p}<0.05)$ crumb hardness and gumminess for all treatments compared to the control (Fig. 2A, B). Fermentation plays an important role in sorghum and nabag as it provides an improvement of nutritional quality. However, T9 (80\% wheat flour and $20 \% \mathrm{NSD}_{\mathrm{LP}}$ ) showed decreased crumb hardness and gumminess compared to the control. During storage for 1 days, T3 (80\% wheat flour and 20\% $\left.\mathrm{SSD}_{\mathrm{LBr}}\right)$ and T6 $(80 \%$ wheat flour and $\left.20 \% \mathrm{SSD}_{\mathrm{LP}}\right)$ increased $(\mathrm{p}<0.05)$ crumb hardness and gumminess, decreased for other samples compared to a control. At 3 day of storage, T6 (80\% wheat flour and $20 \%$ sorghun sourdough starter with LP) increased hardness and T2 (90\% wheat flour and 10\% $\left.\mathrm{SSD}_{\mathrm{LBr}}\right), \mathrm{T} 3$ 
( $80 \%$ wheat flour and $\left.20 \% \mathrm{SSD}_{\mathrm{LBr}}\right)$ and $\mathrm{T} 6(80 \%$ wheat flour and $\left.20 \% \mathrm{SSD}_{\mathrm{LP}}\right)$ increased $(\mathrm{p}<0.05)$ gumminess as shwon in (Fig. 2B). After 5 and 7 days, the hardness increased in T2, $\mathrm{T} 3$, T6 and gumminess at 5 day but increased in $\mathrm{T} 2$ and $\mathrm{T} 3$ on day 7. In fresh bread ( 0 day of storage) addition of sorghum and nabag sourdough starters decreased $(\mathrm{p}<0.05)$ crumb chewiness for all treatments compared to the control (Fig. 2C). T3 and T6 increased ( $p<0.05)$ crumb chewiness on 1day storage, on 3 days of storage, T2, T3 and T6 increased chewiness. After 5 and 7 days, chewiness increased in $\mathrm{T} 2$ and T3 compared to the control. During storage for 1, 3, 5 and 7 days, addition of nabag sourghun starters decreased $(p<0.05)$ crumb hardness, gumminess and chewiness compared to a control. This means nabag sourdough starters increased the shelf-life of wheat bread. Addition of sorghum and nabag soudough starters increased $(p<0.05)$ resilience for all treatments compared to the control (Fig. 2D) on 0 day storage. During storage for 1,3 and 5 days, T5 $(80 \%$ wheat flour and $\left.20 \% \mathrm{NSD}_{\mathrm{LBr}}\right)$ and $\mathrm{T} 9(80 \%$ wheat flour and $20 \%$ $\left.\mathrm{NSD}_{\mathrm{LP}}\right)$ increased $(\mathrm{p}<0.05)$ resilience compared to a control (Fig. 2D). Addition of sorghum and nabag soudough starters increased $(p<0.05)$ cohesiveness for all treatments compared to the control (Fig. 2E). During storage for 1,3 and 5 days T9 $\left(80 \%\right.$ wheat flour and $\left.20 \% \mathrm{NSD}_{\mathrm{LP}}\right)$ increased $(\mathrm{p}<0.05)$ cohesiveness compared to a control (Fig. 2E). Addition of $10 \%, 20 \%$ nabag sourdough starters with $\mathrm{LBr}$ and LP increased the resilience and cohesiveness during the 7 days storage time and decresed resilience and cohesiveness when sorghum sourdough starters were added. The results of the present study indicate that the addition of nabag sourdough starters to improves of textural properties of bread during storage time. The additions of nabag sourdough starters significantly improve the quality and shelf life of wheat bread.

Microbial shelf life studies were conducted on breads (data not shown). The first mould growth was observed on day five for wheat bread (control), giving the breads four days shelf life $\mathrm{T} 2\left(90 \%\right.$ wheat flour and $\left.10 \% \mathrm{SSD}_{\mathrm{LBr}}\right)$ showed mould growth from day seven on, resulting in a shelf life of six days, while the mould growth was not observed in samples (T3,T4,T5,T6,T7,T8 and T9). The results suggest that use of sourdough in bread production is beneficial in improving sensory properties and preventing mould and bacterial spoilage compared to the control. In general, mould growth was not observed in sourdough breads with $\mathrm{pH}$ level $<4.9$ and higher $\mathrm{pH}-\mathrm{levels}$ promoted mold growth. Antimould activity of different LAB strains has been reported [29] and some strains appear to be active even with higher pH-levels [30]. However, role of acidity in the performance of different antimould strains requires further studies to evaluate potential of sourdough to promote microbiological shelf-life without deteriorating flavour. It was concluded that $L$. plantarum was most effective to inhibit microbial spoilage and extended the shelf life of bread compared with the $L$. brevis. Comparatively, sorghum sourdough breads has the lower shelf life than nabag sourdough breads, indicating that nabag sourdoughs improves the shelf life of breads.

\section{Conclusion}

The effect of addition SSDLP, $\mathrm{SSD}_{\mathrm{LBr}}$, $\mathrm{NSD}_{\mathrm{LP}}$ and $\mathrm{NSD}_{\mathrm{LBr}}$ on fermentation properties of dough, baking characteristics and shelf life of wheat bread was investigated. The results indicated that the addition of $\mathrm{SSD}_{\mathrm{LP}}, \mathrm{SSD}_{\mathrm{LBr}}, \mathrm{NSD}_{\mathrm{LP}}$ and $\mathrm{NSD}_{\mathrm{LBr}}$ in dough increased maximum gas fermentation height, total gas volume and gas retention volume whiles sorghum and nabag sourdough starters improved the fermentation properties of doughs. Addition of sorghum and nabag sourdough starters improved the specific volume compared to the control. The addition of $10 \%, 20 \%$ NSD compared with the addition of $10 \%, 20 \%$ SSD resulted in lower loss ratio value. These data suggest that NSD can be substituted to improve the loaf volume and loaf height of composite flour bread. The addition of sorghum and nabag sourdough starters with $L$. plantarum and $L$. brevis increases acidity and lowers $\mathrm{pH}$ of doughs and breads providing mildly acidic bread with improved shelf life. Breads produced with addition of nabag sourdough starters showed higher TTA values and lower $\mathrm{pH}$ values in comparison to the addition of sorghum sourdough. Addition of sorghum and nabag sourdough starter in breads higher moisture content when compared to control and sorghum sourdough starters. The results of the present study indicate that the addition of nabag sourdough starters can significantly improve the textural properties, quality and shelf life of breads during storage time. In conclusion, use of NSD in bread making ensures improvement in the bread quality, namely loaf volume, moisture content and crumb texture, and even the sensory quality of the fresh bread is enhanced compared to the control and sorghum starter. NSD has a positive effect on bread making and is key to making good bread without the use of chemical additive.

\section{Acknowledgements}

We are grateful for the financial supports of the research from Grants $(31071595,20576046)$ from the National Natural Science Foundation of China, the National High Technology Research and Development Program of China (863 Program, 2012AA022200), Key Science and Technology R\&D Program of Zhang Jiagang, Jiangsu Province, China (ZKN1301), Baiho Bake Biotechnology International, Inc. (Nanjing, China), and Magi Bake International, Inc. (Wuxi, China).

\section{References}

[1] Demirkesen Mert, I., Campanella, O. H., Sumnu, G., Sahin, S., 2014. Gluten-free sourdough bread prepared with chestnut and rice flour. In Baltic Conference on Food Science and Technology. LLU.

[2] Wolter, A., Hager, A. S., Zannini, E., Czerny, M., Arendt, E. K., 2014. Impact of sourdough fermented with Lactobacillus plantarum FST 1.7 on baking and sensory properties of gluten-free breads. Eur. Food Res. Technol. 239, 1-12. 
[3] Kasarda, D. D. 2001. Grains in relation to celiac diseases. Cereal Foods World. 46, 209-210.

[4] Galle, S., Schwab, C., Dal Bello, F., Coffey, A., Gänzle, M. G., Arendt, E. K., 2012. Influence of in-situ synthesized exopolysaccharides on the quality of gluten-free sorghum sourdough bread. Int. J. of Food Microbiol.155, 105-112.

[5] Galle, S., Schwab, C., Arendt, E., Gänzle, M., 2010. Exopolysaccharide-forming Weissella strains as starter cultures for sorghum and wheat sourdoughs. Journal of Agricultural and Food Chemistry. 58, 5834-5841.

[6] Schober, T. J., Messerschmidt, M., Bean, S. R., Park, S. H., Arendt, E. K., 2005. Gluten-free bread from sorghum: quality differences among hybrids. Cereal chem.82, 394-404.

[7] Kim, Y., Huang, W., Zhu, H., Rayas-Duarte, P., 2009. Spontaneous sourdough processing of Chinese Northern-style steamed breads and their volatile compounds. Food Chem. $114,685-692$.

[8] Wu, C., Liu, R., Huang, W., Rayas-Duarte, P., Wang, F., Yao, Y., 2012. Effect of sourdough fermentation on the quality of Chinese Northern-style steamed breads. J. Cereal Sci. 56,127133.

[9] Swain, M. R., Anandharaj, M., Ray, R. C., Parveen Rani, R., 2014. Fermented fruits and vegetables of Asia: a potential source of probiotics. Biotechnology research international.2014,250424.

[10] Osman, M. A., Asif Ahmed, M., 2009. Chemical and proximate composition of (Zizyphus spina-christi) nabag fruit. Nutrition. Food Sci. 39, 70-75.

[11] Lockett, Christopher C., Calvert, Louis E. Grivetti, C., 2000. Energy and micronutrient composition of dietary and medicinal wild plants consumed during drought. Study of rural Fulani, Northeastern Nigeria. Int. J. Food Sci. Nutrition. 51,195-208.

[12] Nyanga, L. K. 2012. Ziziphus mauritiana (masau) fruits fermentation in Zimbabwe: from black-box to starter culture development, Wageningen University.

[13] Onyango, C. A., Ochanda, S. O., Mwasaru, M. A., Ochieng, J. K., Mathooko, F. M., Kinyuru, J. N., 2013. Effects of malting and fermentation on anti-nutrient reduction and protein digestibility of red sorghum, white sorghum and pearl millet. J. Food Res. 2, 41.

[14] Curiel, J. A., Rodríguez, H., Acebrón, I., Mancheño, J. M., De Las Rivas, B., Rosario Munoz. 2009. Production and physicochemical properties of recombinant Lactobacillus plantarum tannase. J. Agric. Food Chem. 57, 6224-6230.

[15] AACC International. 2010. Approved Methods of Analysis, 11th Ed. Methods 10-05, 44-40. Available online only. AACC I, St. Paul, MN

[16] Czuchajowska, Z., Pomeranz, Y., 1993. Gas formation and gas retention. I. The system and methodology. Cereal Foods World (USA).

[17] Hathorn, C. S., Biswas, M. A., Gichuhi, P. N., BovellBenjamin, A. C., 2008. Comparison of chemical, physical, micro-structural, and microbial properties of breads supplemented with sweetpotato flour and high-gluten dough enhancers. LWT-Food Sci.Technol. 41, 803-815.

[18] Renzetti, S., Dal Bello, F., Arendt, E. K., 2008. Microstructure, fundamental rheology and baking characteristics of batters and breads from different gluten-free flours treated with a microbial transglutaminase. J. Cereal Sci. $48,33-45$.

[19] Dal Bello, F., Clarke, C. I., Ryan, L. A. M., Ulmer, H., Schober, T. J., Ström, K., Sjögren, J., Van Sinderen, D., Schnürer, J. and Arendt, E. K., 2007. Improvement of the quality and shelf life of wheat bread by fermentation with the antifungal strain Lactobacillus plantarum FST 1.7. J. Cereal Sci. 45, 309-318.

[20] Leroy, F., De Vuyst, L., 2004. Lactic acid bacteria as functional starter cultures for the food fermentation industry. Tren. Food Sci. Technol. 15, 67-78.

[21] Ali, A. A., Mustafa, M. M., 2009. Use of starter cultures of lactic acid bacteria and yeasts in the preparation of kisra, a Sudanese fermented food. Pakistan J. of Nutrition. 8, 13491353.

[22] Axford, D. W. E., Colwell, K. H., Cornford, S. J., Elton, G. A. H., 1968. Effect of loaf specific volume on the rate and extent of staling in bread. J. of the Sci of Food and Agric. 19, 95-101.

[23] Clarke, C. I., Schober, T. J., Arendt, E. K., 2002. Effect of single strain and traditional mixed strain starter cultures on rheological properties of wheat dough and on bread quality. Cereal Chem. 79,640.

[24] Gobbetti, M., Corsetti, A. and Rossi, J., 1995. Interaction between lactic acid bacteria and yeasts in sour-dough using a rheofermentometer. World J. of Microbiol. Biotechnol.11, 625-630.

[25] Arendt, E. K., Ryan, L. A., Dal Bello, F., 2007. Impact of sourdough on the texture of bread. Food Microbiol. 24, 165174.

[26] Torrieri, E., Pepe, O., Ventorino, V., Masi, P., Cavella, S., 2014. Effect of sourdough at different concentrations on quality and shelf life of bread. LWT-Food Sci. Technol. 56, 508-516.

[27] Kaditzky, S., Seitter, M., Hertel, C., Vogel, R. F., 2008. Performance of Lactobacillus sanfranciscensis TMW 1.392 and its levansucrase deletion mutant in wheat dough and comparison of their impact on bread quality. Eur. Food Res. Technol. 227, 433-442.

[28] Thiele, C., Grassl, S. and Gänzle, M., 2004. Gluten hydrolysis and depolymerization during sourdough fermentation. J. agric. Food chem. 52, 1307-1314.

[29] Lavermicocca, P., Valerio, F., Evidente, A., Lazzaroni, S., Corsetti, A., Gobbetti, M., 2000. Purification and characterization of novel antifungal compounds from the sourdough Lactobacillus plantarum strain 21B. Applied and Env. Microbiol. 66, 4084-4090.

[30] Clarke, C. I., Schober, T. J., Dockery, P., O'Sullivan, K. Arendt, E. K., 2004. Wheat sourdough fermentation: effects of time and acidification on fundamental rheological properties. Cereal Chem. 81, 409-417. 